\title{
Structural Analysis of Castanea sativa Mill. Leaves from Different Regions in the Tree Top
}

\author{
Teresa Maria Pinto ${ }^{1 *}$, Maria do Rosário Anjos ${ }^{1}$, Nuno Miguel Martins ${ }^{2}$, José Gomes- \\ Laranjo $^{1}$, Jorge Ferreira-Cardoso ${ }^{1}$ and Francisco Peixoto ${ }^{3}$ \\ ${ }^{1}$ Center for the Research and Technology of Agro-Environment and Biological Sciences; Department of Biology and \\ Environment/School of Life and Environmental Sciences; University of Trás-os-Montes e Alto Douro; PO Box 1013; \\ 5001-801; Vila Real Codex - Portugal. ${ }^{2}$ Electronic Microscopy Facility; University of Trás-os-Montes e Alto \\ Douro; Apartado 1013; 5001-801; Vila Real - Portugal. ${ }^{3}$ Chemistry Department; University of Trás-os-Montes e \\ Alto Douro; Apartado 1013; 5001-801; Vila Real - Portugal
}

\begin{abstract}
The aim of this work was to perform the histological characterization of the C. sativa leaves of three Portuguese cultivars to establish comparison among the leaves of the different quadrants in accord and with the cardinal points of the tree top and among different cultivars of this species, using light microscopy (OM) and scanning electron microscopy (SEM). Measurements were also carried out for the leaf tissue thickness, stomatal density, leaf area in the four tree top quadrants. The leaves turned to the North had lesser thickness of mesophyll mainly due to lower amount of palisade parenchyma. The stomatal density was significantly lower in these leaves, unlike the leaf area that has the highest expression.
\end{abstract}

Key words: C. sativa, leaf anatomy, palisade parenchyma, spongy parenchyma, stomatal density, scanning electron microscopy

\section{INTRODUCTION}

The chestnut is mainly cultivated in Europe, the mediterranean countries, Asia (China, Korea and Japan) and in Northern America, (Bounous, 2002). The European chestnut (Castanea sativa Mill.; family Fagaceae) is an important base of agriculture-forest system in the Mediterranean Europe (Demiate et al., 2001). The chestnut has been major world nuts crop for many years (Crawford, 1995), being Portugal, China, Korea, Italy, Turkey, France, Spain and Greece as the largest producers (Cortizo et al., 1996).
The genetic works in Castanea, show a high variability, due to good adaptation of plants from this genus to the different environmental conditions. The species exhibit morphological and ecological differences too evident within each other, with relationship to vegetative habits, dimensions and their resistance to the extreme biotic and abiotic factors. The plants adaptation to the different habitats, especially to water limitations, can be associated to different ultrastructural characteristics (Esau, 1974). Because leaves are the most flexible organ responding to environmental conditions (Nevo et

*Author for correspondence: tpinto@utad.pt 
al., 2000), its structure reflects more clearly (than the stem and roots) the effects of severe summer drought. Some of these effects in leaves anatomy are a low surface/volume ratio (Karabourniotis and Bornman, 1999; Richardson and Berlyn, 2002) as a result of changes in cell number and cellular dimensions (Chartzoulakis et al., 2000) and a greater density of vascular system and stomata (Bolhar-Nordenkmpf, 1987). Other morphoanatomical traits that help to minimize water loss during drought include leaf rolling (Schawabe and Lionakis, 1996), dense leaf pubescence (Karabourniotis and Bornman, 1999; Liakoura et al., 1999), a thick cuticle and an epicuticular wax layer (Liakoura et al., 1999; Riachardson and Berlyn, 2002), small mesophyll cells and less intercellular space (Bongi et al., 1987; Medialvilla et al., 2001).

The water movement control is a drought adaptation mechanism. For chestnut, there is a conflict between opening the stomata to increase the photosynthesis and closing the stomata to prevent the desiccation. The physiology and environmental control of the chestnut assimilatory process at leaf level has been investigated (GomesLaranjo 2001; Gomes-Laranjo et al., 2005; Gonçalo et al., 2006; Almeida et al., 2007), but there are no reports on the leaves ultrastructural characterization. The purpose of this study was to characterize the chestnut leaves internal anatomy, from four different sides of the tree top and among different cultivars of this species, using optical microscopy (OM) and scanning electron microscopy (SEM).

\section{MATERIALS AND METHODS}

The study was carried out on mature leaves of three cultivars of Castanea sativa Mill. (HVR 3758), cv. Martainha, Longal and Judia, in the experimental field in the University of Trás-osMontes e Alto Douro, Portugal $\left(41^{\circ} 19^{\prime} \mathrm{N}\right.$ and $7^{\circ}$ $44^{`} \mathrm{~W} ; 450 \mathrm{~m}$ elevation). The chestnut leaves, were collected from adult chestnut trees (three trees per cultivars), always at $2 \mathrm{~m}$ height in the tree. From each tree five leaves were collected from each four quadrants in according with the cardinal points: North (N), South (S), East (E) and West (W). All de material was identified for cultivar, tree and quadrant of top tree.

For optical microscopy $(\mathrm{OM})$, small samples from the mean region of leaves were collected $(1 \mathrm{x}$
$1 \mathrm{~cm})$. From these, shoot cross sections, approximately $50 \mu \mathrm{m}$ thick, were cut with a hand microtome, stained in a combination of alum carmine and iodine green (Deysson, 1965) and mounted with synthetic resin on a glass slide. The observations, five slides per sample, were made with a Nikon Labophot-2, provided with a camera Nikon-FX-35DX. The same number and the type of sample were used for scanning electron microscopy (SEM). They were cut with a scalpel $(1 \times 1 \mathrm{~cm})$ and mounted with carbon tape in a stub. Both, lower and upper surfaces, were viewed with an environmental scanning electronic microscope (FEI QUANTA SEM/ESEM) at $20 \mathrm{KV}$ and 5 TORR (666.6 Pa) of pressure in the chamber.

The thickness of leaf blade, palisade and spongy parenchyma, upper and lower epidermis, and stomatal density, were measured in leaf cross sections of fresh material prepared for microscopic (OM and SEM) assessment. Sections were taken from the middle of the leaves to avoid differential thickness along the leaf. In SEM, all the parameters were measured with a XT Docu Soft Imaging System $\mathrm{GmbH}$. The leaf area was measured with an LI-3100 leaf area meter (Li-Cor, Lincoln, NE). Then, for each parameter averages of measurements of all cultivars per quadrant were calculated. The measurement data were submitted to analysis of variance (ANOVA) and the means were compared by the Fisher test with a significance level of 0.05 .

\section{RESULTS AND DISCUSSION}

The Castanea sativa Mill. leaf is a typical mesomorphic leaf with a dorsiventrally flattened lamina. The leaves are simple to arrange in alternate form in the stem. In the European chestnut, several types of leaves could be found (Cortizo et al., 1996). However, there is predominance of the elliptic-lanceolate aspect, elongated-lanceolate and oval-lanceolate. The lamina has a length of $10-25 \mathrm{~cm}$ and a width 5-8 $\mathrm{cm}$. The apex is pointed or acuminated, with a fine tip, the base is symmetrical cordiform and non bite in the adult leaves. The marginal cutting is strongly sawed, with sharp teeth in the prolongation of the minor veins. The leaf coloration changes within the chestnut cultivars. However, there is a clear distinction among the upper surface coloration (green-dark) and the lower surface (clear green) coloration. The petiole 
colour is yellowed or red and the dimensions are changed range from $1.2 \mathrm{~cm}$ to $2.5 \mathrm{~cm}$ of length. (Guerreiro, 1957; Gomes-Laranjo, 1988; Brio et al., 1998).

On the leaves internal anatomy, the upper epidermis consisted of two layers, but the lower epidermis had a single layer (Fig. 1). Their cells had a straight anticlinal walls. However, the cells were more regular in upper than lower surface.
The outer wall was covered by a cuticle. In several cultivars, the lower cuticle layer was less developed than the upper surface, presumably because the presence of thichomes in the lower epidermis in the all leaves of the tree provided protection for the inner tissues. The young leaves showed some disperse thichomes in the upper surface but, thickly pubescent in the lower surface, near the midrib.

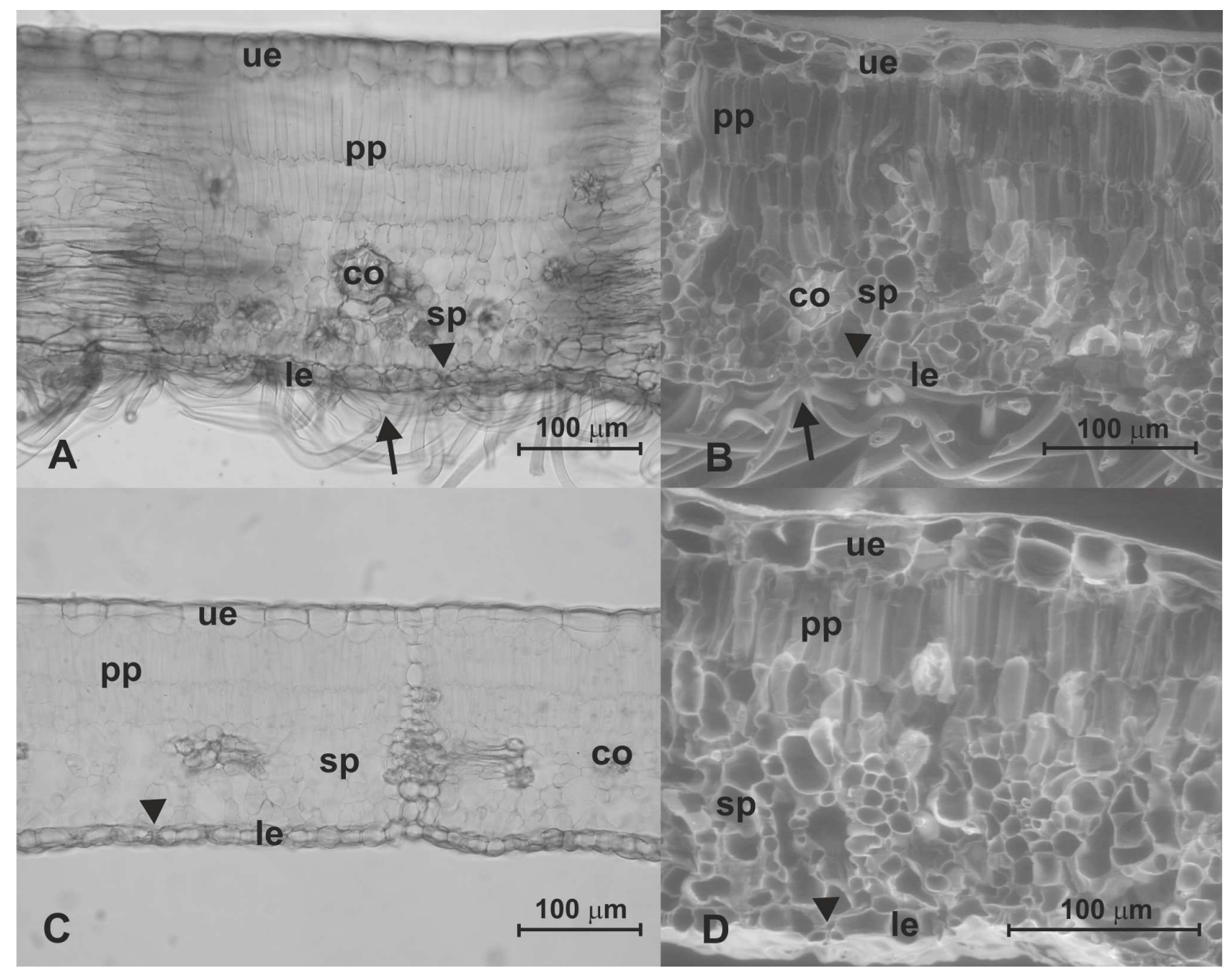

Figure 1 - Optical microscopy (A, C) and scanning electron (B, D) micrographs of the South (A, B) and North $(\mathrm{C}, \mathrm{D})$ of Castanea sativa leaves in cross-section. Leaf epidermis consist in a double layer in upper epidermis (ue) and a single layer in lower epidermis (le). South leaf lamina shows three rows of palisade parenchyma cells (pp) and a relatively compact spongy parenchyma (sp) in the mesophyll. North leaf lamina shows two rows of palisade parenchyma. Note the presence of a cuticle covering the epidermal cells, calcium oxalate crystals in the mesophyll (co), stomata in lower surface (arrowheads) and an abundant trichomes in the lower epidermis (arrows) in A and B micrographs (Martainha cultivar).

At maturity, the upper surface was glabrous, the loer surface of the many European chestnuts cultivars is glabrous. However, the other ones, for example, Martainha cultivar remained very hairy.
These trichomes were not glandular they appeared in tuft form, with thin and cellulosic walls (Figs. 1 A, B). However, there was a marked variability in the trichomes type, density and size, with 
differences between and within the same chestnut cultivars (data not shown).

The mesophyll photosynthetic tissue consisted in palisade and spongy parenchyma. The chestnut mesophyll leaves were heterogeneous and asymmetrical due to the presence of palisade parenchyma in upper surface and spongy parenchyma on lower surface (Fig. 1) The intensity of light and its quality also interfere in the phenotypic expression of the leaves (BolharNordenkampf, 1987). This was evident in the leaves of chestnut. In chestnut, as in any other trees of midsize to large, the regions of shade and sun were well present. Shade and sun leaves differed. The former was from inside the tree top and outside, but focused in North side; the latter was in the regions where the light focused directly, like the outside tree top of the remaining quadrants. Consequently, the internal leaf anatomy differed. The palisade parenchyma had rod shaped cells with a few intercellular air spaces, a great chloroplasts deal, arranged in the rows of two to three layers, as it was a leaf with a North (Figs. 1 C, D) or South (Figs. 1 A, B) exposure. Because of the difference of the layers of the palisade parenchyma, the leaves with exposure to South had a thickness about $20 \%$ higher than the North side (Gomes-Laranjo, 2001) as result of a thin palisade parenchyma. The palisade/spongy parenchyma ratio was high in South and East side (Table 1).

Table 1 - Mean values of leaves tissue thickness, stomatal density and leaf area of three cultivars chestnut leaves harvested in the four tree top sides $(\mathrm{n}=225)$.

\begin{tabular}{ccccccccc}
\hline Quadrant & $\begin{array}{c}\text { leaves } \\
\text { thickness } \\
(\mu \mathrm{m})\end{array}$ & $\begin{array}{c}\text { upper } \\
(\mu \mathrm{m})\end{array}$ & $\begin{array}{c}\text { lower } \\
(\mu \mathrm{m})\end{array}$ & $\begin{array}{c}\text { mesophyll parenchyma } \\
\text { palisade } \\
(\mu \mathrm{m})\end{array}$ & $\begin{array}{c}\text { pal/spo } \\
(\mu \mathrm{m})\end{array}$ & $\begin{array}{c}\text { stomatal } \\
\text { density } \\
\left(\mathrm{mm}^{-2}\right)\end{array}$ & $\begin{array}{c}\text { leaf } \\
\text { area } \\
\left(\mathrm{cm}^{2}\right)\end{array}$ \\
\hline North & $188,7 \mathrm{c}$ & $22.0 \mathrm{c}$ & $15.2 \mathrm{a}$ & $82.4 \mathrm{c}$ & $73.4 \mathrm{~b}$ & 1.12 & $254.8 \mathrm{c}$ & $73.7 \mathrm{a}$ \\
East & $194,6 \mathrm{c}$ & $23.8 \mathrm{c}$ & $15.0 \mathrm{a}$ & $87.8 \mathrm{~b}$ & $66.6 \mathrm{c}$ & 1.32 & $270.5 \mathrm{~b}$ & $69.5 \mathrm{~b}$ \\
South & $239.2 \mathrm{a}$ & $29.1 \mathrm{a}$ & $16.2 \mathrm{a}$ & $110.8 \mathrm{a}$ & $82.2 \mathrm{a}$ & 1.35 & $297.4 \mathrm{a}$ & $70.4 \mathrm{~b}$ \\
West & $208,7 \mathrm{~b}$ & $24.4 \mathrm{~b}$ & $15.4 \mathrm{a}$ & $86.8 \mathrm{~b}$ & $83.6 \mathrm{~b}$ & 1.04 & $292.0 \mathrm{a}$ & $68.1 \mathrm{~b}$
\end{tabular}

Means followed by the same letter are not significant different at $\mathrm{P}<0.05$ (Fisher test).

The spongy parenchyma presented isodiametrical cells of irregular contour and its content was markedly cytoplasmic vacuolar, poor in chloroplasts. In this parenchyma, the intercellular spaces were much larger and in higher numbers compared to the palisade parenchyma (Fig. 1). A rich network of veins facilitated the export of assimilates.

Leaf area of the South, East, West and North of tree top was different being highest leaf area in North leaves than the leaves of South, East and West (Table 1). The shadow leaves were larger, thinner and were adapted to respond more effectively to the little light available and its diffused nature. Each leaf has the ability to acclimatize to the new environmental in order to maintain its photosynthetic efficiency and economy of water. In the leaves that develop in a better position towards light, the mesophyll becomes thick and the proportion of the palisade parenchyma increases in relation to the spongy parenchyma (Bolhar-Nordenkampf, 1987). This assumption was evident in the leaves with South and East exposure.

The presence of calcium oxalate crystals was seen in the leaf mesophyll and the midrib (Figs. $1 \mathrm{~A}-\mathrm{C}$ and $4 \mathrm{~A}, \mathrm{~B}$ ). However, the amount of crystals of calcium oxalate was not similar in all the cultivars. For example, Martainha and Longal cultivars had more calcium oxalate crystals than Judia cultivar (Figs. 2 A, B and Fig. 4 B). 


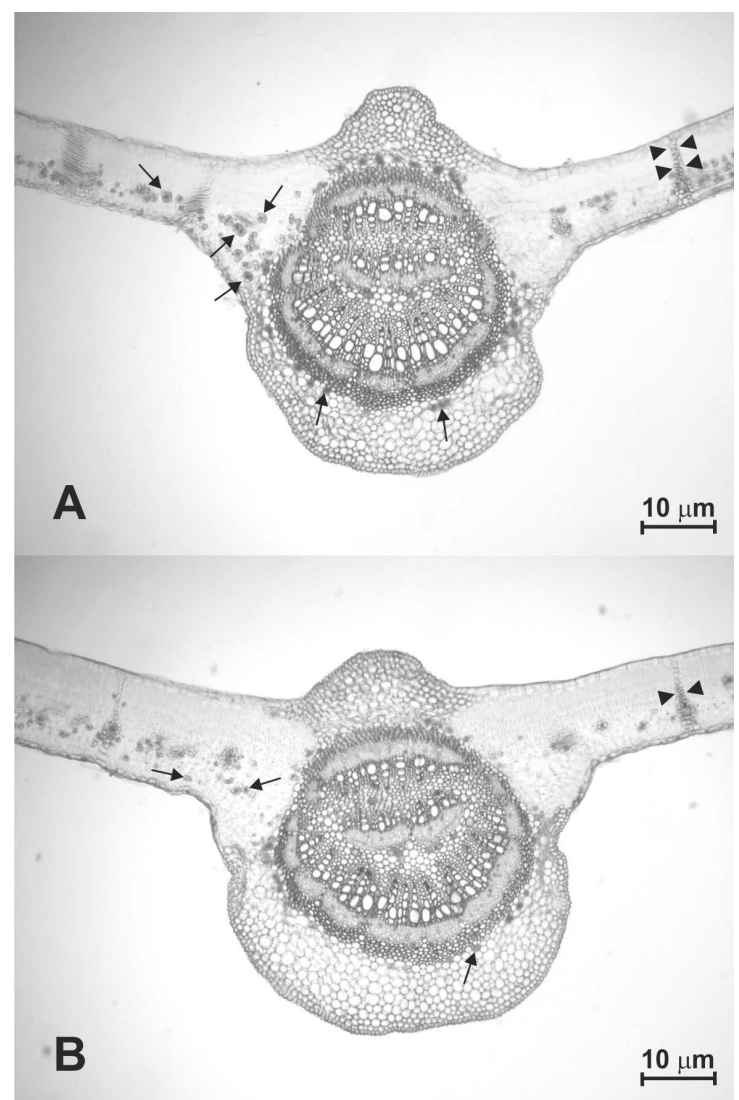

Figura 2 - Optical microscopy micrographs of the Castanea sativa cv Longal (A) and cv Judia (B) leaves in cross-section, showing the difference of calcium oxalate crystals (arrows) abundance in to two cultivars, larger in cv Longal. Note the presence of the bundle sheath extension (arrowheads).

The stomata were present in lower surface (Fig. 3), and the stomatal complex was of anomocytic type (Figs. 3 A, B) in Van Cotthem classification (Van Cotthem, 1970). The stomata were irregularly celled (as in Ranunculaceae) surrounded by an indefinite number of subsidiary cells indistinguishable from neighbouring cells.

No papillae were seen on the cells near the stomata. Two guard kidney shaped cells (about 31 $\mu \mathrm{m}$ in length and $9 \mu \mathrm{m}$ in width) surrounded the slit shaped stomatal aperture which was approximately $13 \mu \mathrm{m}$ in length and $6 \mu \mathrm{m}$ in width. A substomatal chamber was present below the aperture (Fig. 3B).

The number of stomata per unit area and stomatal density varied from cultivar to cultivar, but also within the same cultivar in the same tree. Usually the leaves turned to the South showed higher stomatal frequency than the leaves turned to the North (Table 1). In the same tree, significant differences were found in the parameters measured in the leaves on four tree top sides.

Cortizo et al. (1996) reported that the two species of Asian chestnut, $C$ mollissima and $C$. crenata, had higher stomatal frequency, (469 and 462 stomata $\mathrm{mm}^{-2}$, respectively), than the species $C$. sativa and C. pumila, (254 and 224 stomata $\mathrm{mm}^{-2}$, respectively). The small number of stomata in many Portuguese cultivars of Trás-os-Montes (Pinto et al., 2007) and the development of a protective indumentum can counteract the increment of the transpiration power due to stomatal position. Results that the leaves on the North side had larger leaf area corroborated the results of several authors (Abrams, 1994; Nevo et al., 2000; Pita and Pardos, 2001) showing that the leaves from the xeric areas generally were smaller than the leaves from mesic areas. Because small leaf areas transpire less water than the large leaf areas, the production of small leaves could help reduce the water losses in South, East and West leaves. 


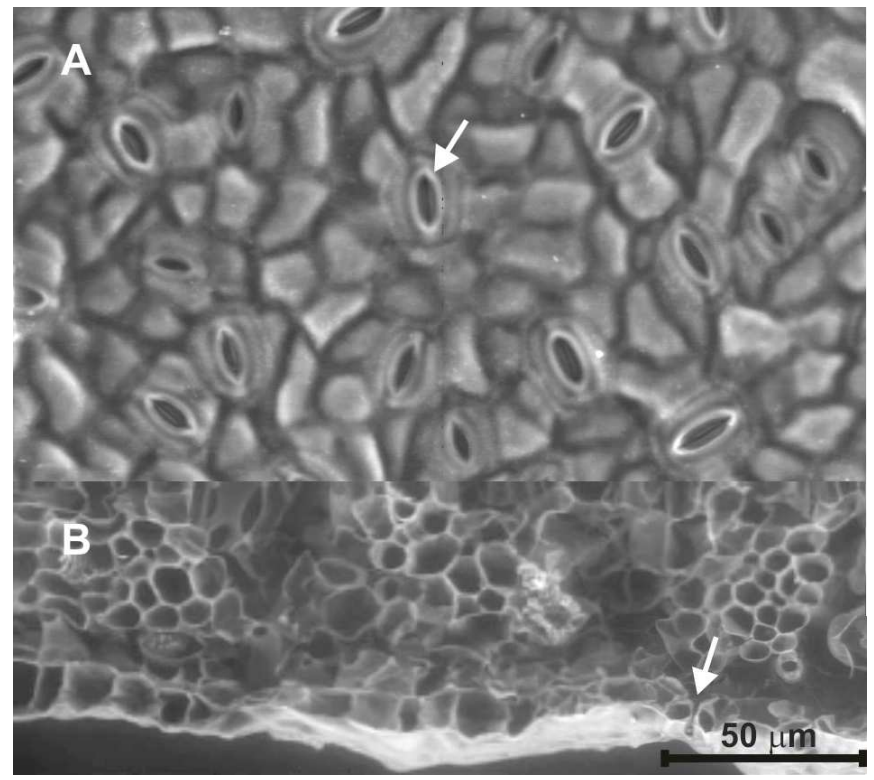

Figure 3 - Stomata scanning electron micrograph on the lower surface (A) and in a cross-section (B) of a $C$. sativa leaf (arrows-stomata).

The chestnut leaves showed penninerved venation. In this type of venation, typical of dicotyledons plants, often the bundle of largest size in the median longitudinal axis of blade was observed, which was the midrib linked to smaller veins called minor veins. The minor veins, present in large numbers in the chestnut, about 20 pairs, were distributed throughout the mesophyll.

The larger diameter veins often had a mass of fibers connecting them to the lower and upper epidermis, called bundle sheath extension (Fig. 2). The fibers provided rigidity to the leaf and were believed to provide an additional means by which the water moved from the bundle out to the mesophyll. Apparently, water moved by capillary action around the fibers rather than through them (Mauseth, 2003).

Usually, the veins were collateral, with the xylem in the direction of the upper surface and phloem in the direction of the lower surface. (Esau, 1974). In the case of chestnut, in the midrib, the veins were collateral double side, where the xylem presented itself in an inside position to the phloem (Figs. 4 A, B). The phloem was followed by the xylem in a more internal position. In a central position, there was again the presence of xylem, followed by phloem. At the direction of lower back surface another strip of xylem, followed by phloem was observed (Figs. 4 A, B).

It should be noted that each set of xylem-phloem was surrounded by a strip of parenchyma, giving the idea of the existence of three veins in the midrib (Fig. 4 A, B). Furthermore, one hemmed of fibre (sclerenchyma) below the phloem was also present. A small amount of collenchyma occured on the top and bottom of midrib, under the epidermis, giving it resistance too. Their cells presented themselves with thickened walls, particularly in the contact angles, being called as angular collenchyma (Fig. 4 C). 


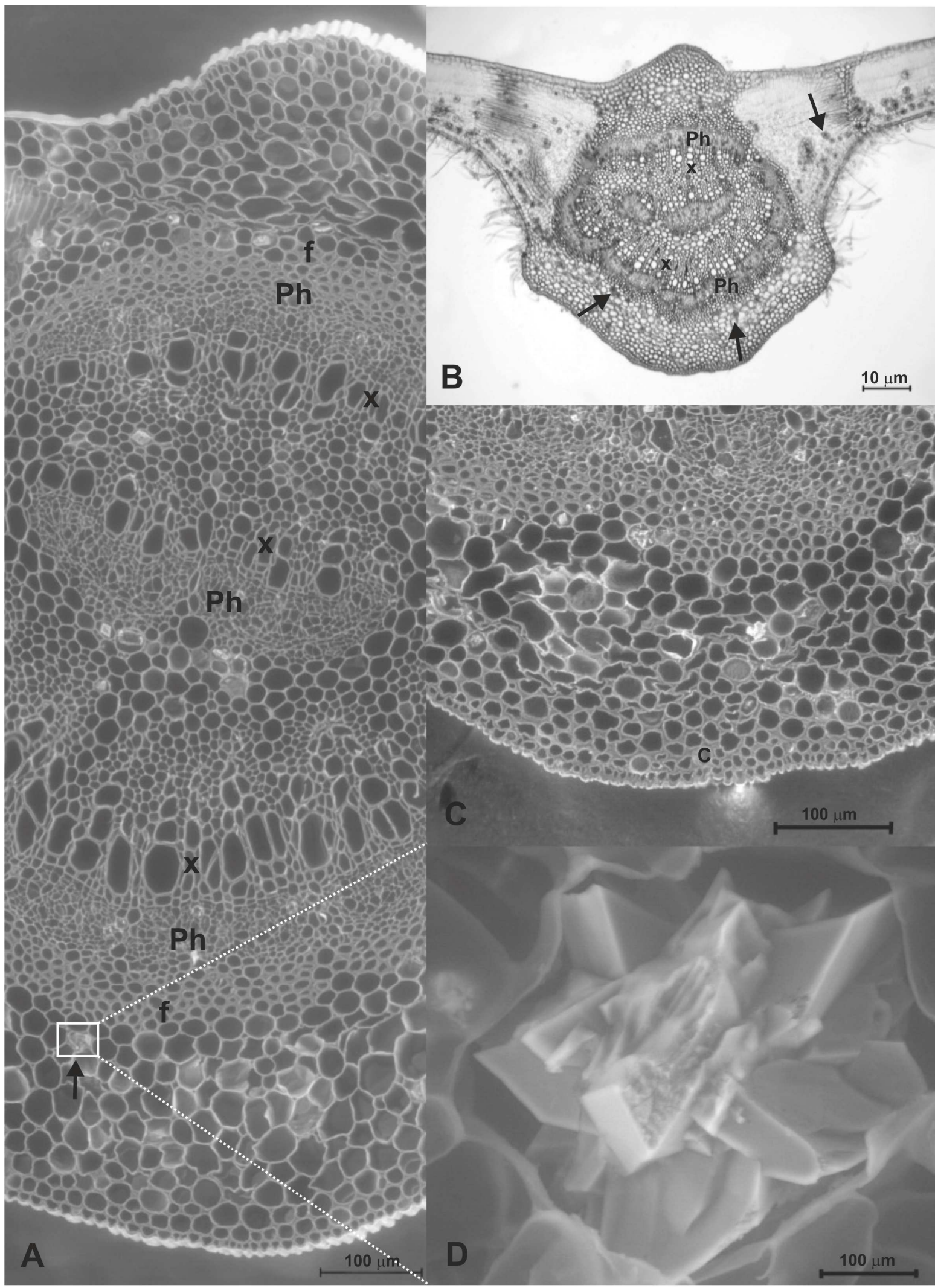

Figura 4 - Scanning electron (A) and optical microscopy (B) micrographs of the midribs of $C$. sativa leaves in cross-section (x-xylem, Ph-phloem, f-fibers, arrows-calcium oxalate crystal. (C) Scanning electron microscopy micrograph detail collenchyma tissue (c) of the lower surface in midrib. (D) Scanning electron micrograph of the calcium oxalate crystal into midrib parenchyma cell. A, C and D - cv Longal; B - cv Martainha. 


\section{ACKNOWLEDGEMENTS}

Authors extend their special thanks to Dr. José Mário Teixeira and Professor Dario Santos for manuscript reviews and their valued suggestions.

\section{REFERENCES}

Abrams, M.D. (1994), Genotypic and phenotypic variation as stress adaptations in temperate tree species: a review of several case studies. Tree Physiol., 14, 833-842

Almeida, P., Dinis, L-T., Coutinho, J., Pinto, T.M.S., Anjos, R., Ferreira-Cardoso, J., Pimentel-Pereira, M., Peixoto, F., Gomes-Laranjo, J. (2007), Effect of temperature and radiation on photosynthesis productivity in chestnut populations (Castanea sativa Mill. cv Judia). Acta Agro. Hung., 55, 193-203

Bolhar-Nordenkampf, H.R. (1987), Shoot morphology and leaf anatomy in relation to photosynthesis. InTecniques in Bioproductivity and Photosynthesis, $2^{\text {nd }}$ edition, eds. J. Coombs, D.O. Hall, S.P. Long, J.M. Scurlock. Pergamon Press, Oxford, pp. 107-117

Bongi, G., Mencuccini, M., Fontanazza, G. (1987), Photosynthesis of olive leaves: effect of light flux density, leaf age, temperature, peltates and $\mathrm{H}_{2} \mathrm{O}$ vapour pressure deficit on gas exchange. J. Am. Soc. Hortic. Sci., 112, 143-148

Bounous, G. (2002), II Castagno. Edagricole, Bologna.

Brio, M.B.D., Lancho, J.F.G., Herrero, J.M.C., (1998), El Castaño. Ediciones Mundi-Prensa, Madrid

Chartzoulakis, K., Bosabalidis, A., Patakas, A., Vemmos, S. (2000), Effects of water stress on water relations, gas exchange and leaf structure of olive tree. Acta Hortic., 537, 241-247

Cortizo, E.V., Madriñan, M.L.V., Madriñan, F.J.V., (1996), El Castaño. Edilesa, Léon

Crawford, M. (1995), Chestnuts. Production and culture. Agroforest. Research Trust, 8-11

Demiate, I.M., Oetterer, M., Wosiacki, G. (2001), Characterization of the chestnut (Castanea sativa, Mill) starch for industrial utilization. Braz. Arch. Biol. Technol., 44, 69-78

Deysson, G. (1965), Éléments D'anatomie Des Plants Vasculaires. Société D'édition Dénseignement Supérieur, Paris

Esau, K. (1974), Anatomia das Plantas com Sementes. $14^{\text {a }}$ Edition, Edgard Blücher Ltda, São Paulo

Gomes-Laranjo, J. (1988), Aspectos de produtividade fotossintética em Castanea sativa Mill.. Relatório Final de Estágio, Universidade de Trás-os-Montes e Alto Douro, Vila Real, Portugal

Gomes-Laranjo, J. (2001), A Fotossíntese em castanheiro. Estudo integrado a diferentes níveis de organização biológica. PhD Thesis, Universidade de Trás-os-Montes e Alto Douro, Vila Real, Portugal
Gomes-Laranjo, J., Coutinho, J.P., Ferreira-Cardoso, J., Pimentel-Pereira, M., Ramos, C., Torres-Pereira, J. (2005), Assessment to a new concept of chestnut orchard management in vegetative wall. Acta Hort., 693, 707-712

Gonçalo, E., Peixoto, F., Pinto, T.M.S., Anjos, R., Pimentel-Pereira, M., Ferreira-Cardoso, J., Wong Fong Sang, H.W., Gomes-Laranjo J. (2006), Assessment to the high temperature effect on chestnut seedlings growth. Biochim. Biophy. Acta, 271-272

Guerreiro, M.G. (1957), Castanheiros - Alguns Estudos Sobre a Sua Ecologia e o Seu Melhoramento Genético. ISA, Lisboa

Karabourniotis, G., Bornman, J. (1999), Penetration of UV-A, UV-B and blue light through the leaf trichome layers of two xeromorphic plants, olive and oak, measured by optical fibre microprobes. Physiol. Plant., 105, 655-661

Liakoura, V., Stavrianakou, S., Liakopoulos, G., Karabourniotis, G., Manetas, Y. (1999), Effects of UV-B radition on Olea europaea: compararisons between a greenhouse and a field experiment. Tree Physiol., 19, 905-908

Medialvilla, S., Escudero, A., Heilmeir, H. (2001), Internal leaf anatomy and photosynthetic resourse-use efficiency: interspecific and intraspecific comparisons. Tree Physiol., 21, 251-259

Mauseth, J.D. (2003), Botany. An Introduction to Plant Biology. 3rd Edition. Jones and Bartlett Publishers, Sudbury, Massachusetts

Nevo, E., Bolshakova, M.A., Martyn, G.I., Musatenko, L.I., Sytnik, K., Pavlieek, T., Beharav, A. (2000), Drought and light anatomical adaptative leaf strategies in three woody species caused by microclimatic selection at "Evolution Canyon". Isr. J. Plant Sci., 48, 33-46

Pinto, T.M.S., Anjos, R., Gomes-Laranjo, J. (2007), O Castanheiro sob o ponto de vista botânico e ecofisiológico. Caracterização biológica: folha, caule, raiz, flor e fruto. In-Castanheiros, eds. J. GomesLaranjo, J. Ferreira-Cardoso, E. Portela, C. GomesAbreu. Programa Agro, Código 499 - Contributo para a difusão do conhecimento das cultivares portuguesas de castanheiro, Vila Real, pp. 63-93

Pita, P., Pardos, J.A. (2001), Growth, leaf morphology, water use and tissue relations of Eucaliptus globules clones in response to water deficit. Tree Physiol., 21, 599-607

Riachardson, A., Berlyn G. (2002), Changes in foliar spectral reflectance and chlorophyll fluorescence of four temperate species following branch cutting. Tree Physiol., 22, 499-506

Schawabe, W., Lionakis, S. (1996), Leaf attitude in olive in relation to drought resistance. J. Hortic. Sci., 71, 157-166

Van Cotthem, R.W. (1970), A classification of stomatal types. Bot. J. Linn. Soc., 63, 235-246 